\title{
Infected wound healing and antimicrobial effects of Chenopodium ambrosioides and Mitracarpus scaber
}

\author{
Magbéfon TETTEGAH, Kwashie EKLU-KADÉGBÉKU, A. KODJO AKLIKOKOU, \\ Amégnona AGBONON, Comlan De SOUZA and Messanvi GBÉASSOR * \\ Centre de Formation et de Recherches sur les Plantes Médicinales (CERFOPLAM). Laboratoire de \\ Pharmacologie/Physiologie, Faculté des Sciences, Université de Lomé. B.P : 1515 Lomé, Togo. \\ *Corresponding author, E-mail: gbeassor@tg.refer.org, Tel.: (228) 2250877.
}

\begin{abstract}
Chenopodium ambrosioides Linn. (Chenopdiaceae) and Mitracarpus scaber Zucc. (Rubiaceae) are herbal medicinal plants. They are commonly used in Togolese folk medicine to treat skin infections such as infected wounds, dermatoses, and scabies. The aim of this work was to evaluate the wound healing and antimicrobial properties of the two plants. Firstly, we evaluated the infected wound healing property of the two plants. We induced and treated infected wound in Wistar rats as follows. We inserted a sterile needle under the skin of the animal previously anesthetized by ether. Along the needle, we made an incision of $2 \mathrm{~cm}$ of length. The wound was infected with 24 hours colonies of P.aeruginosa. One infected wound was created per animal. $0.5 \mathrm{~g}$ of ointments prepared form $C$. ambrosioides and M. scaber leaf extracts, was applied twice a day. Secondly, we conducted antimicrobial assays with extracts prepared with the leaves of the plants. Staphylococcus aureus, Pseudomonas aeruginosa, Candida albcans, Escherichia coli and Salmonella sp. were used in this study. Infected wound in control group healed in 12.6 \pm 0.245 days. The ointment from $C$. ambrosioides or M. scaber leaf extracts, significantly and respectively reduced this mean time to $07.04 \pm 0.245$ $(\mathrm{P}<0.01)$ and $06.4 \pm 0.245(\mathrm{P}<0.01)$ days. The extracts showed antimicrobial activities against all tested strains. $C$. ambrosioides and $M$. scaber possess wound healing and antimicrobial properties. These findings support their traditional use in treatment of skin infections.

(C) 2009 International Formulae Group. All rights reserved
\end{abstract}

Keywords: antimicrobial activity, Chenopodium ambrosioides, Mitracarpus scaber, ointments, skin infected wounds.

\section{INTRODUCTION}

Skin infections are very dangerous because they allow pathogens to reach other parts of the organism through the bloodstream (Robert and Kupper, 1999). These germs are involved in a large number of diseases including infectious endocardities (Entenza et al., 2004), arthritis and lung infections (Shirtliff and Mader, 2002). Chenopodium ambrosioides Linn. (Chenopodiaceae) and Mitracarpus scaber Zucc. (Rubiaceae) are herbal medi-cinal plants, which are distributed over large areas in Togo. C. ambrosioides has been shown to be analgesic (Amole and
Yusuf, 1999), ascaricidal and insecticidal (Chiason and Bostanian, 2004). It is also hepatotoxic (Rufa et al., 2002), cytotoxic and genotoxic (Gadano et al., 2006). Antiinflammatory (Ekpendu et al., 1994), antifungal (Obiodum, 1999), hepatoprotective, antiulcer (Aklikokou et al., 1995) properties have been demons-trated for $M$. scaber. The pulp of the leaves of $C$. ambrosioides is topically used for abscesses; its leaves are also used in treatment of wounds and abscesses in Ghana (Ekpendu et al., 1994). Oedema and pain are treated with the sap of the plant; the leaves are also used for treating scabies and 
other dermatoses (Ekpendu et al., 1994). The two plants are commonly used in Togolese folk medicine to treat skin abscesses, infected wounds, viral, fungal and bacterial dermatoses (Adjanon-houn et al., 1986). There is no scientific report which supports the traditional use of the plants for treatment of skin infections. Then, we aimed to evaluate the antimicrobial and infected wound healing properties of the two plants.

\section{MATERIALS AND METHODS \\ Plant material}

We collected $C$. ambrosioides and $M$. scaber in April and October 2006 respectively. They were collected at Tsevie, a locality situated at $35 \mathrm{~km}$ in the north of Lomé (Togo). The samples were identified at the Department of Botany and Plant Ecology of the Faculty of Sciences, University of Lomé (Togo). A voucher specimen of each plant was deposited in the herbarium of this Department. Aerial parts of the plants were washed, cut into pieces, shade dried and used for extract preparation.

\section{Tested microorganisms}

Staphylococcus aureus (gram positive bacterium), Escherichia coli, Pseudomonas aeruginosa, Salmonella sp. (Gram negative bacteria) and Candida albicans (fungus) were used for the in vitro antibacterial and antifungal tests. All of these germs were available in the Laboratory of Microbiology of the "Ecole Supérieure de Techniques Biologiques et Alimentaires, ESTBA", University of Lomé, Togo.

\section{Culture mediums used}

We used for bacteria, Müller Hinton agar and broth. For $C$. albicans, we used Sabouraud agar, Sabouraud broth and Chloramphenicol Sabouraud.

\section{Drugs used}

Gentamycin, nystatin and 3\% aureomycin cream were used as reference drugs. They were bought in pharmacies.

\section{Animals}

Male and female Wistar rats weighing between $80 \mathrm{~g}$ and $90 \mathrm{~g}$ were used. Animals were bred at the Laboratory of Physiology/ Pharmacology of the Faculty of Sciences,
University of Lomé. They were housed under standard environmental conditions (temperature and humidity). They had a 12 hours light/dark cycle. The animals had free access to food and water.

\section{Ointment preparation}

The ointments were formulated as $20 \%$ extracts of the plants in shea nut butter base. Sixteen (16) grams of purified shea nut butter were melted. $4 \mathrm{~g}$ of the extract were added to the purified shea nut butter and mixed. The purified shea nut butter was supplied by the Department of Chemistry, Faculty of Sciences, University of Lomé.

\section{Extract preparation}

We soaked in hydroethanolic solvent (v/v) for 72 hours, one hundred grams (100 g) of the dried material. Solutions obtained were filtered and evaporated to dryness. Evaporation was made under vacuum (Buchi) at $40{ }^{\circ} \mathrm{C}$. Yields were $13 \%$ for $M$. scaber and $9.5 \%$ for C. ambrosioides.

\section{Pseudomonas aeruginosa infected wound induction}

We used the modified method of Gisby et al. (2002) for induction of the infected wound. The method is described below. Animals were anesthetized by inhalation of ether. The fur on the back and flanks of the animal was clipped. The skin was cleaned with $95 \%$ ethanol. A sterile needle was inserted under the skin. An incision of $2 \mathrm{~cm}$ was made along the needle. The wound was infected with 24 hours colonies of $P$. aeruginosa. The inoculum contained $10^{8}$ $\mathrm{cfu} / \mathrm{ml}$ of bacterial suspension. One infected wound was made per animal.

\section{In vitro antimicrobial activity}

We added to $0.5 \mathrm{ml}$ of $C$. ambrosioides or M. scaber extract, $10 \mu \mathrm{l}$ of germ suspension. The same volume of germ suspension was added to $0.5 \mathrm{ml}$ of gentamycin (bacteria) or nystatin (C. albicans). A volume of $10 \mu \mathrm{l}$ of the germ suspension was also added to $0.5 \mathrm{ml}$ of Müller Hinton or Sabouraud broth. Each suspension contained $10^{4} \mathrm{cfu} / \mathrm{ml}$. The tubes were incubated at $37^{\circ} \mathrm{C}$ for bacteria and $30^{\circ} \mathrm{C}$ for the fungus. 24 hours later, the medium was spread on the appropriate agar plates. Each medium was 
duplicated. Müller Hinton and Chloramphenicol Sabouraud agars were used for bacteria and $C$. albicans respectively. Inhibition rate was calculated as follow: I.R $=100\left(1-\mathrm{X} / 10^{5}\right)$. I.R: Inhibition rate, $\mathrm{X}$ : mean number of colonies on the two assay agar plates. Müller Hinton and Chloramphenicol Sabouraud agars served as control. Colonies numbered on these plates were considered $10^{5}$ (de Souza and Amegavi, 1993).

Minimum Inhibition Concentrations (MICs) were the lowest concentrations which inhibited growth of the microorganisms more than $80 \%$.

\section{Treatment of the infected wounds}

We started the treatment when skin lesions were formed. $0.5 \mathrm{~g}$ of the ointment was applied twice a day until total wound healing. Animals were randomly divided into five groups. Each group contained five animals. Animals were individually housed in each group. Group I consisted of rats with infected wounds not treated (control group). In group II, the infected wound was treated with shea nut butter. Shea nut butter was the vehicle for the administration of the extracts. The infected wound of group III was treated with $20 \%$ M. scaber extract ointment. Group IV infected wound was treated with $20 \% C$. ambrosioides extract ointment. Group V was the positive control group; its rats with infected wounds were treated with $3 \%$ aureomycin ointment.

\section{Statistical analysis}

Results are expressed as mean \pm SEM.

Statistical comparisons were made using the Student $t$-test. A $\mathrm{P}$ value of $<0.05$ was considered statistically significant.

\section{RESULTS}

Infected wounds of the non treated control group and the ones of the group treated with shea nut butter healed in twelve days. The ointment from C. ambrosioides or $M$. scaber reduced this period respectively to $7.4 \pm 0.245$ days $(\mathrm{P}<0.01)$ and $6.4 \pm 0.245$ days $(\mathrm{P}<0.01)$. Infected wounds treated with $3 \%$ aureomycin ointment healed in $4.0 \pm 0.178$ $(\mathrm{P}<0.001)$ days (Table 1). Extract activities did not significantly $(\mathrm{P}>0.05)$ differ from the one exhibited by $3 \%$ aureomcin cream.

$C$. ambrosioides and $M$. scaber extracts inhibited all tested microorganisms. The best activities were obtained with $M$. scaber extract. This extract was more potent on $S$. aureus, $C$. albicans and $P$. aeruginosa, MICs are respectively $0.03 \mathrm{mg} / \mathrm{ml}, 0.03 \mathrm{mg} / \mathrm{ml}$ and $1 \mathrm{mg} / \mathrm{ml}$ (Table 2).

\section{DISCUSSION}

Bacterial infections as well as diabetic skin infections, surgical wounds and orthopaedic infections are very dangerous because they rapidly cause septicaemia. Septicaemia can be fatal if it is not quickly diagnosed. Skin candidosis and these bacterial infections are more dangerous for patients with depressed immunity. We infected rats' wounds with Pseudomonas aeruginosa colonies. Pseudomonas aeruginosa is a gram negative bacterium. Gram negative bacteria like $P$. aeruginosa and Klebsiella pneumoniae cause skin infections (Hendricks et al., 2001). The infected wounds induced were significantly healed by the ointments prepared from $C$. ambrosioides or $M$. scaber leaf extracts. Furthermore the extracts prepared

Table 1: Effects of $M$. scaber and C. ambrosioides extracts ointments on $P$. aeruginosa skin infected wounds in rats.

\begin{tabular}{lc}
\hline Groups & Wounds healing time (days) \\
\hline Group I & $12.6 \pm 0.245$ \\
Group II & $12.2 \pm 0.374$ \\
Group III & $07.4 \pm 0.245^{*}$ \\
Group IV & $06.4 \pm 0.245^{*}$ \\
Group V & $04.0 \pm 0.178^{*}$ \\
\hline
\end{tabular}

Group I: Non treated control group. Group II: Treated with shea nut butter only. Group III: treated with $20 \%$ C. ambrosioides extract ointment. Group IV: treated with $20 \%$ M. scaber extract ointment. Group V: treated with 3\% aureomycin ointment (positive control). Treatment consisted of $0.5 \mathrm{~g}$ of the ointment applied twice a day. Values are means \pm SEM of 5 rats. * significantly different from control ( $\mathrm{P}<0.01)$. 
Table 2: Antimicrobial activities of C. ambrosioides and M. scaber extracts.

\begin{tabular}{lcccc}
\hline \multirow{2}{*}{ Microorganisms } & \multicolumn{3}{c}{ Minimum inhibition concentration $(\mathbf{m g} / \mathbf{m l})$} \\
\cline { 2 - 5 } & C. ambrosioides & M. scaber & Gentamycin & Nystatin \\
\hline S. aureus & 50.00 & 0.03 & 0.01 & N.T \\
E. coli & 50.00 & 12.50 & 0.1 & N.T \\
P. aeruginosa & 75 & 1.00 & 0.1 & N.T \\
Salmonella sp. & 75.00 & 20.00 & 0.1 & N.T \\
C. albicans & 50.00 & 0.03 & N.T & 0.01 \\
\hline \multicolumn{4}{c}{ NT: non tested. } & \multicolumn{4}{c}{}
\end{tabular}

from their leaves significantly inhibited the growth of $P$. aeruginosa in vitro in our study. Gram positive bacteria such as $S$. aureus, $S$. pyogenes are also involved in skin infections (Hendricks et al., 2001). The growth of $S$. aureus was significantly inhibited in vitro by the extract prepared from leaves of M. scaber in our study. Robert and Kupper (1999) also obtained inhibition of growth of $S$. aureus with extract from $M$. scaber. They obtained, with the extract of $M$. scaber, the inhibition of growth of other gram positive strains, which cause skin infections, such as Streptococcus faecalis and Bacillus subtilus. Furthermore, M. scaber has been shown to possess antimicrobial properties against gram negative bacteria involved in skin infections such as Klebsiella pneumoniae (Ruffa et al, 2002). C. albicans is also involved in skin infections (Kugulberg et al., 2005). We obtained in vitro, inhibition of growth of $C$. albicans with the extracts of C. ambrosioides and M. scaber. Shirtllif and Mader (2002) also obtained in vitro inhibition of $C$. albicans with extract of M. scaber. C. ambrosoides has been shown to possess antimicrobial properties against other microorganisms involved in skin infections like Trichophyton mentagrphytes, Mycobacterium tuberculosis M37Rv29 and Microsporum audounii (Kishore et al., 1999; Lall and Meyer, 1999). The rapid healing of the infected wounds in our study could be explained by inhibition of the germ in vivo and acceleration of cicatrisation process. The extracts could also have accelerated the defence of the rats in vivo.

\section{Conclusion}

We induced in rat, $P$. aeruginosa skin infected wounds. These infected wounds were significantly healed with ointments prepared from $C$. ambrosioides and $M$. sacber hydroethanolic extracts. Furthermore, the extracts inhibited in vitro growth of some strains commonly associated with skin infections such as $S$. aureus, $P$. aeruginosa and $C$. albicans. C. ambrosioides and $M$. scaber possess infected wound healing and antimicrobial properties. These results support the traditional use of the two plants in skin infection treatment.

\section{REFERENCES}

Adjanohoun E, Ahyi M, Aké A, Akpagana K, Chibon P, El Hadj Eyme J, Garba M, Gbeassor M, Goudote E, Hodoute K, Houngon P, Keita A, Keoula Y, KlugaOcloo W, Lo I, Samevi K, Taffame K. 1986. Contribution aux Etudes Ethnobotaniques et Floristiques au Togo $\left(1^{\mathrm{èr}}\right.$ édn). Agence de Coopération Culturelle et Technique; 181.

Aklikokou K, Gbeassor M, Napo K. 1995. Action anti-ulcéreuse de quelques plantes. Pharm. Méd. Tradit. Afr., 8: 5560.

Amole O, Yusuf G. 1999. The analgesic effects of Chenopodium ambrosioides. J. Nat. Prod. Med., 3: 26-27.

Chiasson A, Bostanian N. 2004. Ascaricidal properties of a Chenopodium. J. Econ. Entomol., 97: 1373-1377.

De Souza C, Amegavi K. 1993. Etude de l'activité antimicrobienne des extraits totaux de dix plantes médicinales. Rev. Méd. Pharm. Afri., 2:107-115.

Ekpendu T, Akah P, Adesomujo A, Okogun J. 1994. Antiiflammatory and antimicrobial activities of Mitracarpus scaber extracts. Int. J. Pharmacol., 32: 191-196.

Entenza M, Vouillamez J, Glausser P, Moreillon P. 2004. Efficacy of genoroxacin on treatment of experimental endocarditis due to Staphylococcus 
aureus or viridans group Streptococci. Antimicrob. Agents Chemother, 48: 8696.

Gadano A, Gurni A, Carballo M. 2006. Argentine folk medicine; genotoxic effects of Chenopodiaceae family. $J$. Ethnopharmacol., 103: 246-251.

Gisby J, Bryant J. 2002. Efficacy of a new cream formulation of mupirocin: comparison with oral and topical agents in experimental skin infections. Antimicrob. Agents Chemother, 44: 250260.

Hendricks J, Burd A, Jeffrey O, Andrew W, Gordon D, Baary J. 2001. Synergy between Staphylococcus aueus and $P$.aeruginosa in rat model of orthopaedic wounds. J. Bone Joint Surg., 83: 855-865.

Kishore N, Chansounia J, Dubey N. 1999. Antidermatophytic action of essential oil of Chenopodium ambrosioides and an ointment prepared from it. Phytother. Res., 10: 453-456.

Kugulberg E, Norstro T, Peterson K, Duvold T, Dan I, Diarmaid H. 2005.
Establishment of a superficial skin infection model in mice using Staphylococcus aureus and Streptococcus pyogenes. Antimicrob. Agents Chemother., 49: 3435-3440.

Lall N, Meyer J. 1999. In vitro inhibition of drug resistant and drug sensitive strain of Mycobacterium tuberculosis by ethnobotanically selected South African plants. J. Ethnopharmacol., 66: 347-354.

Obiodum O. 1999. Antimicrobial agents from some nigerian plants. Niger. J. Nat. Prod. Med., 3: 26-27.

Ruffa M, Ferraro G, Wagner M, Calcagno M, Campos R, Cavallaro B. 2002. Cytotoxic effect of Argentine medicinal plant extract on human hepatocellular carcinoma cell line. J. Ethnopharmacol., 79: 333- 339.

Robert C, Kupper S. 1999. Inflammatory skin diseases, T-cells and immune surveillance. N. Engl. J. Med., 341: 1817-1828.

Shirtliff E, Mader J. 2002. Acute septic arthritis. Clin. Microbiol. Rev., 5: 527544. 